\title{
Smart and Sustainable Local Communities in Global Covid-19 Pandemic Conditions
}

\author{
Pudzis Edgars, Krutova Una, Geipele Sanda, Kalinka Maris, Auzins Armands \\ Riga Technical University, Latvia
}

\begin{abstract}
The COVID-19 pandemic has brought many changes in everyone's life. Villages and rural areas are among the places where people have sought refuge in order to stay away from others and to be able to comply with government regulations during an emergency. Crisis conditions require the choice of means of communication, remote employment and self-help and self-support. Smart and strong communities or villages this means more than only technologically and economically advanced communities - can be more successful in overcoming the crisis. This study analyses the characteristics of smart communities, the external factors influencing the functioning of these communities, as well as the specific circumstances caused by the first wave period of the Covid-19 pandemic (from March 2020 till June 2020). Collecting basic information on smart communities, external factors and special circumstances, and using the methods of analysis, comparison and drawing conclusions, the most important factors that have positively affected communities in the pandemic conditions have been taken into account within the framework of this study, clearly indicating the sustainability and development advantages of smart communities in Latvia. Nobody knows what will be "new normal" after COVID-19, but some benefits of smart thinking are noticed.
\end{abstract}

Keywords: COVID-19, smart villages, spatial planning; village development; community development; signs of the smart village; neighbourhood planning

\section{Introduction \\ General Information about the Research}

The aim of this study is to investigate the options for the local community in the first period of COVID-19 restrictions set by the government of Latvia and whether it is possible to use the advantages of smart villages and strong communities in this period. The local community described in this study emphasises villages in the territory of Latvia, which are located on the coast of the Gulf of Riga.

Accordingly, the following objectives have been set: (1) to describe the theoretical aspects of the concept of smart villages; (2) to show how COVID-19 restrictions affect the behaviour of communities (3) to find out a positive role of smart and strong communities in unpredictable obstacles when "face-toface" communication is restricted; (4) to find answers to the open question: "Can social life be provided remotely for a long time and where the reality remains - social and cultural activities?"; and (5) to open up a discussion on the potential future and "new normal".

For this study, the main research questions are: "Could it be possible to find something evolving for communities in the COVID-19 situation? Is a smart community better suited to difficult, unpredictable conditions?"

The present research has been conducted using various datasets available from statistical sources, as well as summarising theoretical information about the concept of SMART village, regulatory framework and identifying SMART village features by means of logical data analysis and comparative methods.
The study of several restrictions in Latvia regarding COVID-19 covers the period of 12 March 2020 till 10 June 2020 - the first period of an emergency situation [14].

In Latvia, several restrictions were set for three months: teleworking, if possible; distance learning in schools; distance keeping, gathering restrictions for up to five people. At the same time, different services such as public transport, education services, culture services, etc. were reduced or cancelled [14]. In addition, the population began to make extensive use of digital technologies and the opportunities they provide for mutual communication, school and university learning processes, the purchase of necessary goods and business management. Many of these processes are also included in the Smart Village concept and are applicable to the management of economic processes and the provision of primary needs. Moreover, strong communities more used interaction activities to improve self-care and mutual assistance services.

The research territorial areas cover small villages in Latvia. As example territories two coastal villages in Latvia - Tuja and Garupe are chosen, because this research is a part of research paper series that are created under INTERREG Central Baltic programme project "Coast4us".

The study shows the strengths of smart community potential, which have positively affected a community/village ability to respond to the challenges posed by COVID-19 pandemic in Latvia. 
The research uses: (1) literature review method for an overview of theoretical aspects of the smart village concept and local community identification; (2) the analysis of secondary and primary data; and (3) discourse analysis and synthesis as well as graphical methods for designing the main research results. The results are summarised in Table 1 at the end of the study.

\section{The Idea of Smart Village Concept}

Smart Villages are communities in rural areas that use innovative solutions to improve their resilience, building on local strengths and opportunities. They rely on a participatory approach to develop and implement their strategy to improve their economic, social and/or environmental conditions, in particular by mobilising solutions offered by digital technologies. Smart Villages benefit from cooperation and alliances with other communities and actors in rural and urban areas. The initiation and implementation of Smart Village strategies may build on existing initiatives and can be funded by a variety of public and private sources. Communities in rural areas can include one or several human settlements, without any restrictions regarding the administrative boundaries or the number of inhabitants. As regards eligibility conditions for support, EU Member States may use definitions of rural areas as provided for by the OECD, EUROSTAT or other definitions. A participatory approach means active participation of the local community in the drawing up and decisionmaking regarding the Smart Village strategy. During the implementation phase, the participatory approach will ensure that the needs for capacity building and the training of people are properly addressed. Digital technologies include, for example, information and communication technologies, the exploitation of big data or innovations related to the use of the Internet of Things (IoT). They act as a lever to enable Smart Villages to become more agile, make better use of their resources and improve the attractiveness of rural areas and the quality of life of rural residents. The use of digital technologies is not a precondition for becoming a Smart Village. Where possible, highspeed broadband will facilitate the deployment of digital solutions. Smart Village strategies respond to the challenges and needs of their territory by building on their local strengths and assets. Strategies must determine short-, medium- and longterm goals. Progress must be measurable through performance indicators that will be set in a roadmap. These roadmaps should be reviewed at regular intervals to allow for continuous improvement. Strategies may aim, for example: to improve access to services (in various fields such as health, training or transport), to enhance business opportunities and

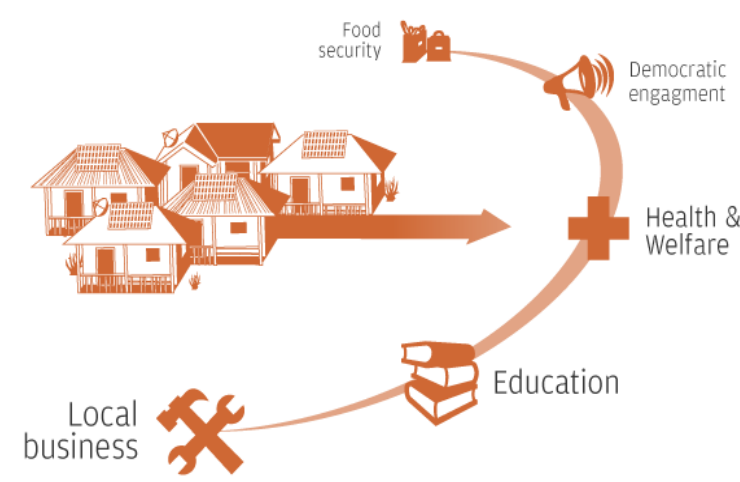

Fig. 1. The concept of Smart Village [11]

create jobs, to the development of short food supply chains and farming practices, to the development of renewable energies, to the development of a circular economy, to better exploitation of natural resources, to adapt to climate change, to preserve the environment and biodiversity, to a better valorisation of the cultural heritage for a greater tourist attractiveness etc. [16].

On 22 May 2018, EU Commissioner Phil Hogan said, "Smart villages are all about making different policies work together to find better, smarter ways to promote holistic rural development. It is about harnessing existing and emerging technologies and social innovations to add value to the lives of our citizens. It is about giving villages the tools to address their own challenges while also making a contribution to the bigger challenges facing society as a whole" [15].

Smart village is an advanced concept of off-grid community where every component of the basic human rights relates to smart technology. Renewable and sustainable energy service performs as a facilitator for development in the smart village concept. Figure 1 shows the smart services available in a smart village [8].

Smart villages are rural areas and communities that use their existing strengths and values, as well as develop new opportunities to create new added value. In smart villages, traditional things and new approaches are sought and improved through digital communication technologies, innovation and better application of knowledge for the benefit of citizens [7].

Smart villages are based on people, i.e., rural communities that take the initiative to find practical solutions both to solve existing problems and to make the most of new opportunities for the transformation of rural areas in the future [4].

The term "smart" implies:

- The use of digital technology where it is applicable, not because it is modern or up-todate. Smart villages often use the added value of digital technologies, but this is only one of the tools to improve performance; 


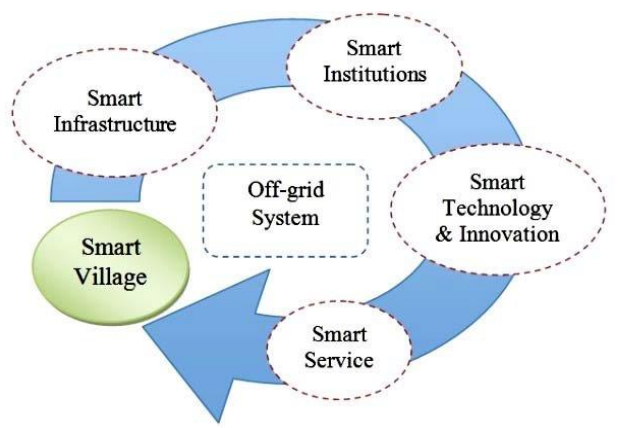

Fig. 2. The concept of Smart Village [8]

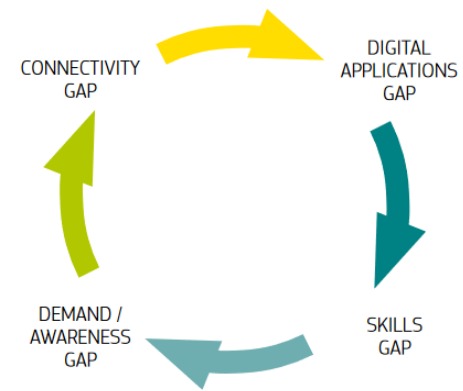

Fig. 3. Links between connectivity, digital applications, skills and demand gaps [15]

- Thinking outside the village. Some of the current Smart Village practices stop working in the village area, but there are also some that include the surrounding rural area, village groups, small towns and cooperation with large cities;

- New cooperation and the development of new forms of cooperation - between farmers and other entrepreneurs in rural areas, between municipalities, the private and public sectors, cooperation takes place from the bottom up and from the top down;

- Care for oneself. There is no single common model or solution to the Smart Village approach - the main emphasis is on local people and their ability to use local resources, apply their knowledge and take the initiative.

It is clear from these smart village cases that a community cannot rely on internal resources in a crisis without going beyond villages or community borders. There is a need for a link that ensures cooperation with neighbouring communities and municipal and state institutions (see Figure 2).

To make rural communities benefit from digital strategies and create the conditions for Smart Villages, it is necessary to use all three components of the digital divide while taking into account the specific needs of each rural area and the existing landscape of policy support such as:

- Broadband infrastructure;

- Promoting the uptake of digital services;

- Digital skills and literacy.

They need to be addressed together in digitisation strategies [15]. Figure 1 shows links between connectivity, digital applications, skills and demand gaps.

According to Figure 3, the three aforementioned components reinforce each other, so if not addressed together, it would lead to a low level of awareness, demand and uptake of digital technologies, which in turn damage the business case for further investments.

\section{Overview of Precautions}

for Distribution of COVID-19

The World Health Organisation gives simple precautions with regard to the distribution of COVID-19, that are mainly connected with washing hands, distancing, good respiratory hygiene, etc. [3].

These established guidelines require people to be careful and limit their activities to a minimum when meeting others. In view of the above, individuals lose direct contact within the framework of business and social communication. As a result, communities lose their traditional approach of direct social and economic communication between neighbours or neighbouring communities.

Latvia separately by Cabinet of Ministers Order No. 103 of 12 March 2020 imposed certain restrictions on education, assembly, international passenger transport, health care and other. There are the main points for restrictions [14]:

- State and local government institutions shall evaluate and, as far as possible, ensure the provision of face-to-face services remotely;

- To terminate the study process in person in all educational institutions, all types of the educational process in full form outside educational institutions and to provide studies remotely;

- To allow the gathering of both indoor and outdoor people at such organised events for up to 25 people, ensuring epidemiological and social distance;

- To determine that the place of performance of cultural, religious activities, entertainment, sports and other recreational places shall start not earlier than at 6.30 and end not later than 24.00;

- For persons designated by the Centre for Disease Prevention and Control as COVID-19 infectious disease contact persons - Self-isolation at the place of residence (home quarantine) and availability must be provided for 14 days in order to be able to communicate and cooperate with the family doctor and other medical personnel;

- From 17 March 2020, to stop the international carriage of passengers by air, sea, road and rail, with the exception of passenger transport by state aircraft and military transport, as well as private and business flights (with a maximum of five passengers); to resume international air, sea, bus and rail passenger transport to or from Lithuania and Estonia as of 15 May 2020. 


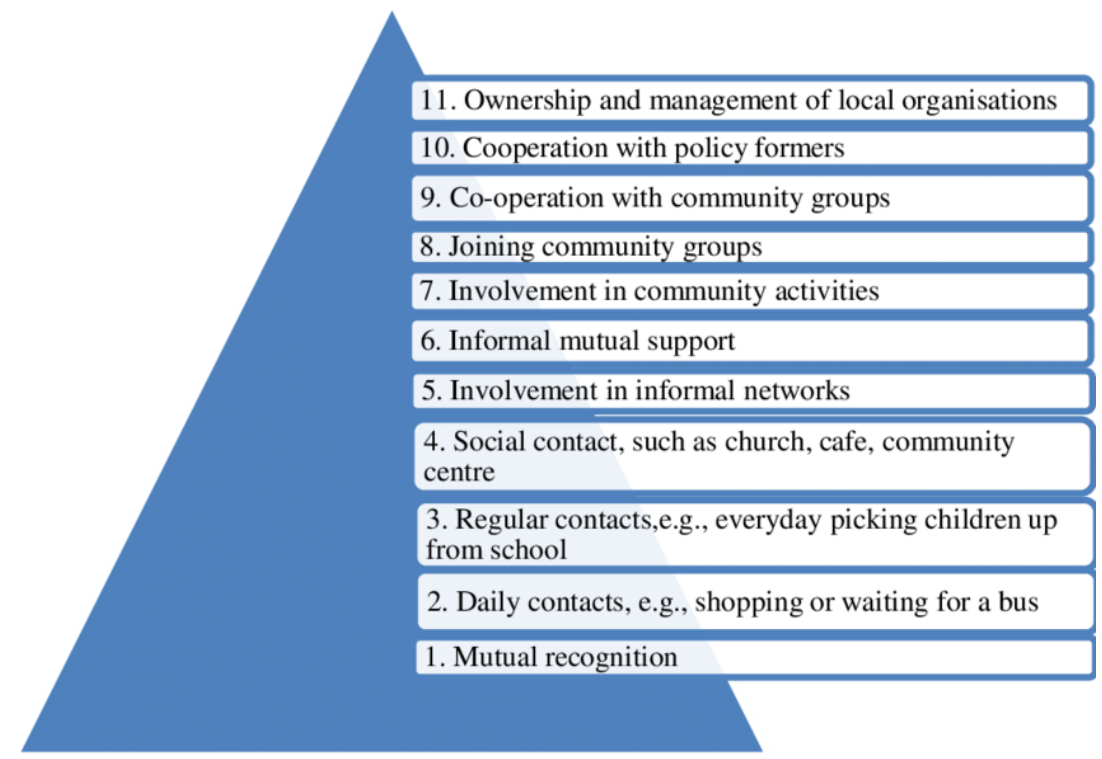

Fig. 4. Community interaction scale [13]

These restrictions practically stopped face-toface meetings outside one household and necessitated adaptation to work and social activity.

\section{The Idea of Local Village Community}

The status of a village shall be granted and revoked by a municipality council, based on the local government territorial planning, in which the village border is defined and the need for developing a village is justified. The status of a village may be granted to such section of a municipality territory in which concentrated building is present (or is planned), people are living permanently, and the appropriate infrastructure has been developed [13].

Taking into account that historically in Latvia, the villages have not formed as built-up areas but, among other things, are based on interpersonal ties and needs, as well as, in theory, such a territorial limitation forms a community, further in the present study the authors will examine the integrated development of villages and communities or territorial communities that have a clearly defined operational limitation [13].

When discussing the existence of a community and its strength during an emergency, it is necessary to focus on the basic needs of the community and the performance of daily affairs: social communication, business activities, the performance of basic functions, necessary needs, etc.

Towards an even deeper understanding of community development, Thomas (1991) [18] has created the community interaction scale, which is divided into two blocks and grouped into grades from 1 to 11 (see Figure 4). The scale consists of grades that are separated because they distinguish between lower, regular and obvious community interaction aspects (from 1 to 6) and higher/more complex and formal organisational aspects of community life (from 7 to 11) [ 13].
The present study prioritises digital technology and smart village opportunities for social and economic interaction within the community. The benefits of strong communities are analysed in the discussion section and the results are shown in Table 1.

\section{Literature Review and Analytical Assessment}

According to the Smart Communities Guidebook (1997) [9], a "smart community" is a community in which members of local government, business, education, health care institutions and the general public understand the potential of information technology, and form successful alliances to work together to use technology to transform their community in significant and positive ways.

\section{Smart Village and Business}

Smart Village is a relatively new concept within the realm of EU policy making. The emerging concept of Smart Village refers to rural areas and communities that use their existing strengths and assets as well as develop new opportunities. In Smart Village, traditional and new networks and services are enhanced by means of digital, telecommunication technologies, innovations and better use of knowledge for the benefit of inhabitants and businesses. Digital technologies and innovations may support the quality of life, higher standard of living, public services for citizens, better use of resources, less impact on the environment, and new opportunities for rural value chains in terms of products and improved processes. The concept of Smart Village does not propose a one-size-fits-all solution. It is territorially sensitive, based on the needs and potentials of the respective territory, as well as strategy-led, i.e., supported by new or existing territorial strategies. Technology is important along with investments in infrastructure, 


\begin{tabular}{|c|c|}
\hline MULTI-SERVICE HUBS & MOBILE SERVICES \\
\hline $\begin{array}{l}\text { Colocation into multi-service hubs provides one means by } \\
\text { which rural service businesses can survive or even thrive. } \\
\text { These can be planned, as is happening in rural Finland and } \\
\text { Belgium. Equally, hubs can develop in a more organic way, as } \\
\text { when a garage takes on the post office and then develops a } \\
\text { food retail function. }\end{array}$ & $\begin{array}{l}\text { These can provide essential services to local communities } \\
\text { while at the same time ensure the viability of small firms } \\
\text { by increasing their customer base. Examples include } \\
\text { mobile dentists, vets, building maintenance and shops of } \\
\text { various kinds. }\end{array}$ \\
\hline DIGITAL DIVERSIFICATION & SHORT SUPPLY CHAINS \\
\hline $\begin{array}{l}\text { Architects, lawyers, consultants, and other professionals } \\
\text { can all provide a wide range of services using digital } \\
\text { solutions.. }\end{array}$ & $\begin{array}{l}\text { These have long been an adaptive strategy for small food } \\
\text { firms to gain a competitive edge. }\end{array}$ \\
\hline
\end{tabular}

Fig. 5. The main strategies for business in small territories [2]

business development, human capital, capacity and community building. Good governance and citizen involvement are also key factors. Smart Village would typically pay attention to e-literacy skills, access to e-health and other basic services, innovative solutions for environmental concerns, circular economy application to agricultural waste, promotion of local products supported by technology and ICT, implementing and taking full benefit of smart specialisation agri-food projects, tourism and cultural activities, etc. The concept of Smart Village covers human settlements in rural areas, as well as the surrounding landscapes [7].

Common Agricultural Policy (CAP) includes six priorities where the last priority (No.6) discusses social inclusion and economic development. This priority is divided into three groups: facilitating diversification, creation and development of small enterprises, as well as job creation, fostering local development in rural areas and enhancing the accessibility, use and quality of information and communication technologies (ICT) in rural areas [12].

Private sector businesses need to generate profit to survive. The key question is whether the level of demand is sufficient to justify a business proposition: will the income be sufficient to cover costs and generate enough profit to pay back loans and reward other sources of finance? For large companies operating on a national or global scale the answer often is "no", they can do better elsewhere. For smaller, more territorially rooted enterprises, there appear to be four main strategies (see Figure 5) [2].

COVID-19-related restrictions, which called for staying at home, "drove" part of the population to the countryside. In Latvia, in addition to the apartment in the city, citizens often also own a country property or holiday house.

In order to be able to do the work, to follow the lectures and classes, almost everyone was forced to raise their IT gaps, especially in remote communication.
Within a few days after an emergency situation had been announced, theoretical strategies were implemented in life (see Figure 3):

- Digital diversification - it turned out that public employees, teachers, lecturers, architects, etc., can really work from home;

- Farmers and local restaurants learned to build websites and began delivering products to neighbours at home, strengthening and putting into practice short supply chains;

- Larger supply businesses expanded the supply areas from Riga suburb to the whole territory of Latvia; reduced delivery price; started services for small, one-family orders and supplemented the range of goods with basic necessities, such as disinfectants, creating a special combination of multi-service hub and mobile service (mobile multi-service).

\section{Villages/Communities and IT Technologies}

During the COVID-19 pandemic, many people in many countries, as well as in Latvia, lived outside the cities, managing their daily processes from villages, small towns or homesteads. Starting from 13 March 2020, many people in Latvia moved from cities to areas outside the cities or small towns and there was a need to ensure both high-quality internet connection and its availability. Figure 4 shows the migration of people from large cities to rural areas by analysing the mobile network connection. A study conducted at the University of Latvia in cooperation with Latvia Mobile Network operator shows that it is possible to provide remote connection in Latvia in practically all areas that are not related to physical production. Figure 4 shows mobile activities in the mobile network before COVID-19, i.e., the change in activity in March 2019 compared to March 2020. To analyse these two periods before and during the first wave of COVID-19 in Latvia, we see the activities change from cities to rural areas $[1 ; 5 ; 10]$. 


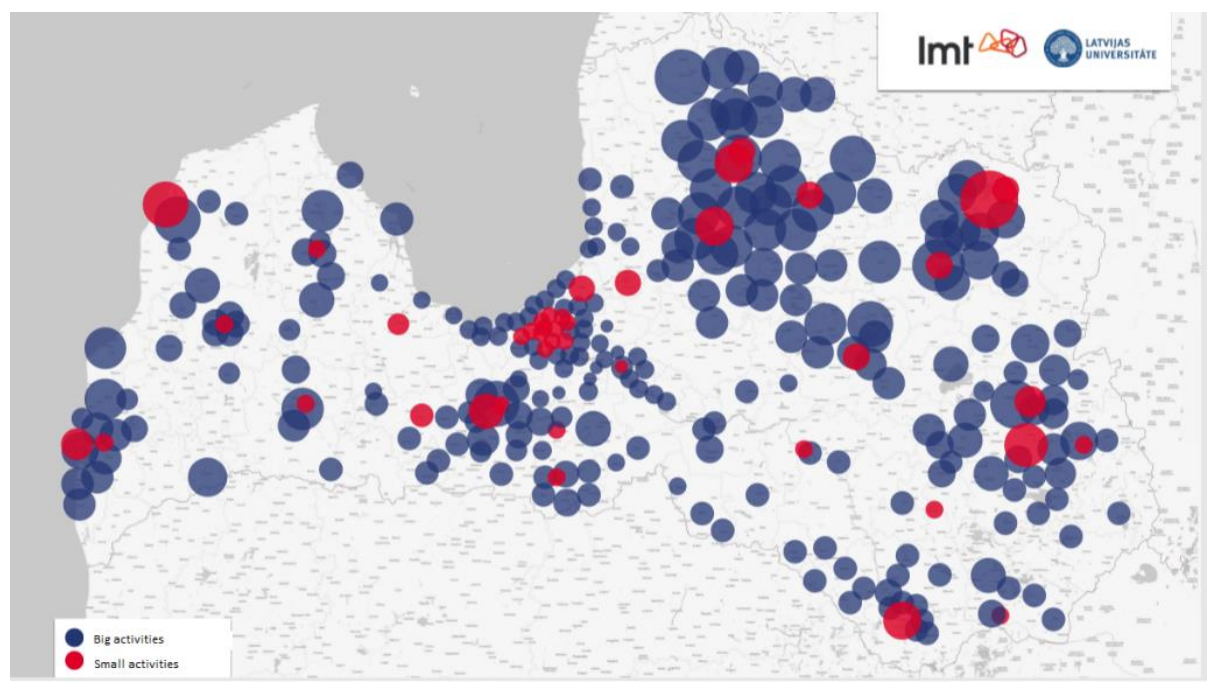

Fig. 6. Activities in the mobile network provided by Latvia Mobile Network [10]

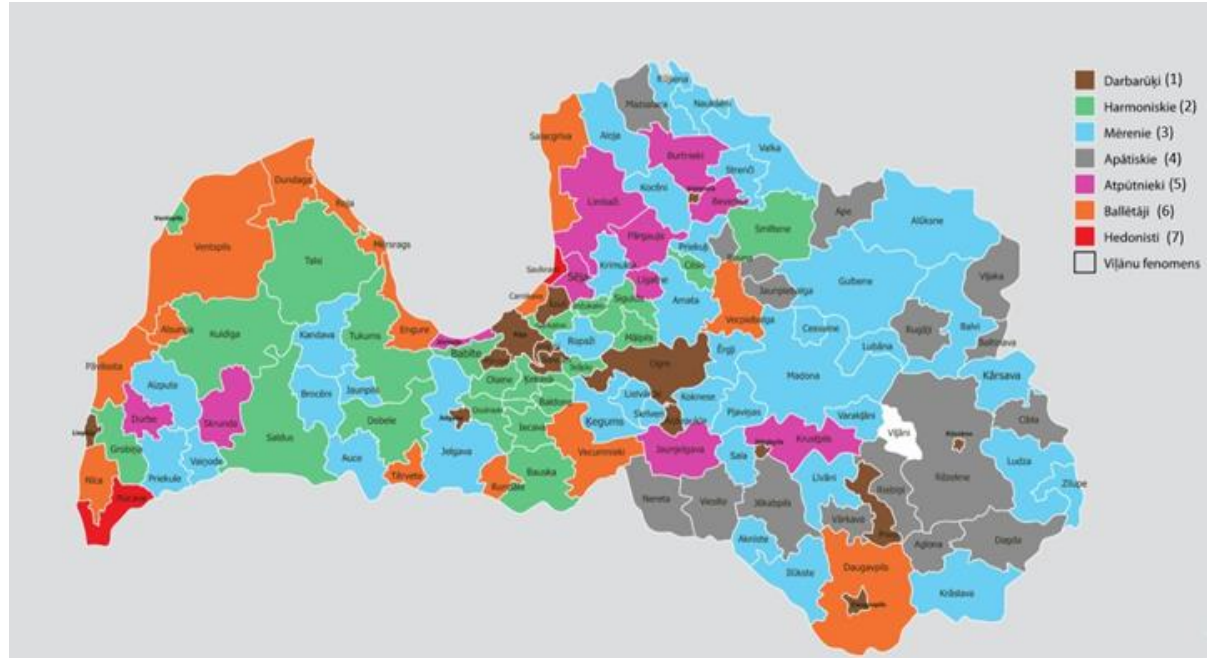

Fig. 7. Economic development index of Latvia's regions (in the Latvian language) [5]

Figure 6 shows that in the Latvian capital, Riga, and other major cities of Latvia, the mobile network activity decreased in March 2019 (before COVID-19) (red circles), but in rural areas, the mobile network activity increased in March 2020 (during COVID-19) (blue circles). Thus, it can be concluded that if there is a sufficient IT infrastructure and the work can be done remotely, then people move to the countryside, outside large cities, as well as to the villages.

Researchers of the University of Latvia analysed data of mobile network (LMT) events (incoming and outgoing calls and SMS) over the period from 25 July 2015 to 20 January 2017 (64733760 entries) and, according to mobile phone usage habits, an index map for the economic development of Latvia's regions was created (see Figure 7).

As can be seen in Figure 5, all regions of Latvia were classified into eight groups:

(1) - workaholic, denoting community members with high activity on weekdays and moderately low activity on weekends;
(2) - harmonious, denoting community members with high and moderate activity on weekdays and moderate activity on weekends;

(3) - moderate, denoting community members with moderate economic activity on weekdays and weekends;

(4) - apathetic, denoting community members with low activity on weekdays and moderate activity on weekends;

(5) - holidaymakers, denoting community members with moderately low activity on weekdays and moderately high activity on weekends;

(6) - partygoers, denoting community members with low activity on weekdays but high activity on weekends;

(7) - hedonists, denoting community members with minimal activity on weekdays and maximum activity on weekends;

(8) - Viḷāni phenomenon (only one municipality has these characteristics) denoting the activity of the area as moderate on weekdays and moderately low on weekends. 


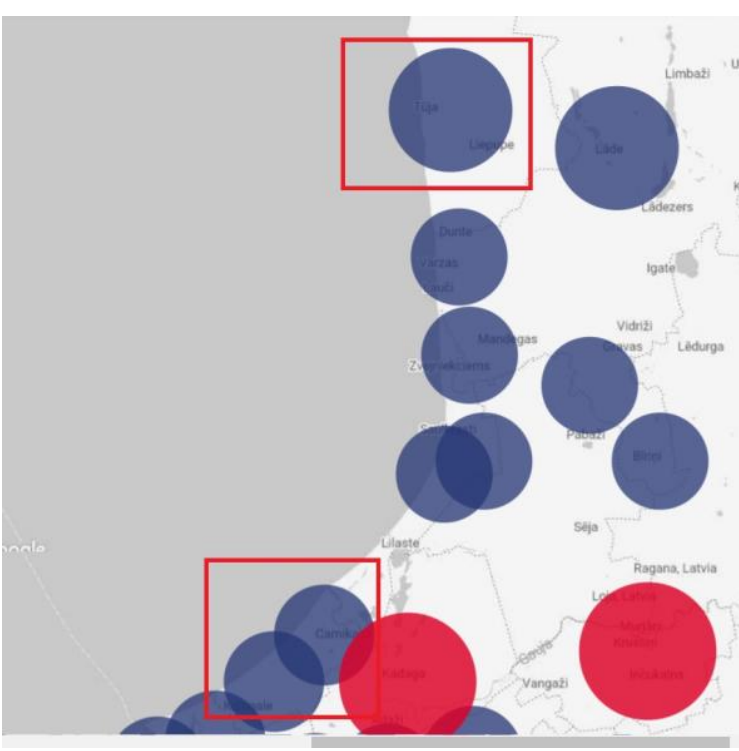

Fig. 8. Changes in the economic activity index in March 2020 compared to March 2019 in Tüja village of Salacgriva district and Garupe village of Carnikava district [10]

To better reflect the changes in the economic activity index during the first period of COVID-19 and to show the activity of villages, the authors demonstrate two Latvian village profiles as example territories in Figure 8 - Tūja village in Salacgrīva district and Garupe village in Carnikava district, where both villages correspond to the profile of partygoers according to the above classification, which means that before the COVID-19 people were active on weekends in these villages.

The information presented in Figure 6 about Tūja village in Salacgrīva district and Garupe village in Carnikava district, which according to the classification provided in Figure 5 correspond to the profile of partygoers before the COVID-19, shows that when the first state of emergency came into force people moved to rural areas, where they lived and worked, including more active former partygoer villages of Tūja and Garupe transformed from partygoers to workaholic.

Another mobile network provider Tele2 conducted a survey of the people. The population survey was conducted in cooperation with the research company BERG Research. The survey took place from 27 March to 1 April 2020, and 707 respondents participated. The consumption of data by telephones in Tele 2 network increased by $50 \%$ in the first half of 2020. The average consumption of mobile data per SIM card in the network of the mobile operator Tele 2 increased by $50 \%$ in the first half of 2020. According to Tele2, the average data consumption per SIM card in the company's network reached 15.2 gigabytes (GB). The company also mentions that a rapid average increase in data consumption by smartphones has been since the beginning of 2020, but an increase in data consumption has not only been affected by the spread of coronavirus and restrictions to combat it, as the population's habits change. "Data consumption continues to grow year by year. We see this both after the average data consumption and the increase in the number of connections of unlimited tariff plans. Unlimited data plans are currently the most popular," said Valdis Vancovičs, Chairman of the Board of Tele2 [19].

\section{Analytical Assessment of Socioeconomic Activities}

Not only experimental but also official information collected by the Central Statistical Bureau shows the impact of COVID restrictions on employees' behaviour and economic activity.

The employed population, who had the opportunity, switched to remote work. Figure 9 shows proportion of remote employees by the main economic activity sectors: manufacturing sector (NACE section B-F (B - Mining and quarrying, C Manufacturing, D - Electricity, gas, steam and air conditioning supply, E - Water supply, sewerage, waste management and remediation activities, $\mathrm{F}$ Construction)), trade and services sector (NACE section $\mathrm{G}-\mathrm{N}$ ( $\mathrm{G}$ - Wholesale and retail trade; repair of motor vehicles and motorcycles, $\mathrm{H}$ - Transportation and storage, I - Accommodation and food service activities, J - Information and communication, $\mathrm{K}-$ Financial and insurance activities, L Real estate activities, M Professional, scientific and technical activities, $\mathrm{N}$ - Administrative and support service activities)), other service sector (NACE section $\mathrm{O}-\mathrm{U}(\mathrm{O}-$ Public administration and defence, compulsory social security, P - Education, Q - Human health and social work activities, R - Arts, entertainment and recreation, $\mathrm{S}$ - Other service activities, $\mathrm{T}$ - Activities of households as employers, undifferentiated goods- and services-producing activities of households for own use, U - Activities of extraterritorial organisations and bodies)) [17].

According to Figure 7, remote work in some economic activity sectors can be implemented quickly and successfully, but in others - such as in non-automatized manufacturing - not.

The data of the Central Statistical Bureau show that senior specialists worked most often $(42.7 \%)$ remotely, slightly more than a third (34.2\%) of managers and slightly less than a third (32.4\%) of specialists. In June 2020, $63.7 \%$ of remote employees worked full-time, $18.3 \%$ worked regularly 3-5 days a week, and 7.8\% worked regularly 1-2 days a week. $5.2 \%$ of employees worked remotely a few days a month, but $5.0 \%$ regularly worked part-time or a few hours.

With the end of the state of emergency (the first wave) in Latvia, the proportion of remote employees decreased. In June 2020, $15.5 \%$ (117.1 thousand) of employees aged 15-74 worked remotely, which was 


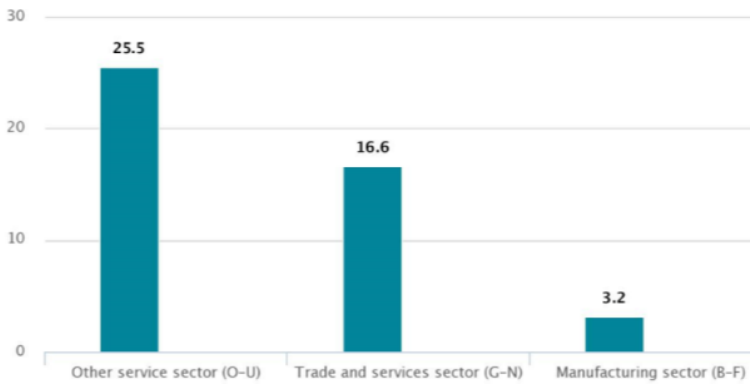

Fig. 9. Proportion of remote employees by economic activity sector in June 2020 (as per cent) [17]

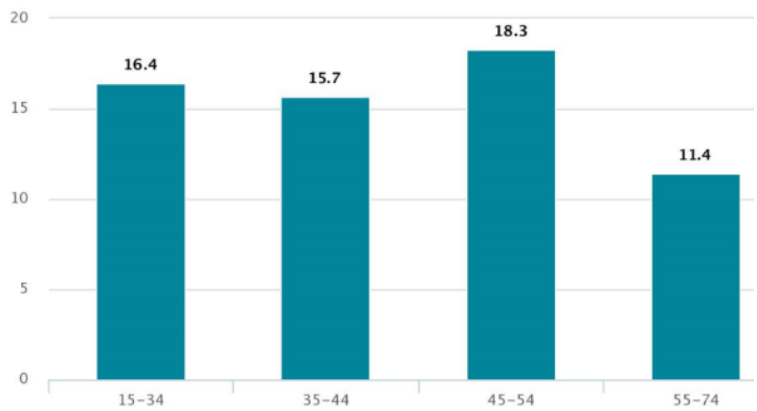

Fig. 10. The proportion of remote employees to the total number of employees of the corresponding age group in June 2020 (as per cent) [6]

2.7 percentage points (18.8 thousand) less than in May 2020, according to the results of the Labour Force Survey conducted by the Central Statistical Bureau. $70 \%$ of women and $30 \%$ of men worked remotely [6].

The highest number of remote employees was in the age group 15-34 years (31.2\%), slightly less $(27.0 \%)$ - in the age group 45-54 years (see Figure 10). The highest number of remotely employed men $(35.7 \%)$ was in the age group 35-44 years, but women $(31.7 \%)$ - in the age group $15-34$ years.

As shown in Figure 8, the highest share of remote employees $(18.3 \%)$ to the total number of employees in the corresponding age group in June 2020 was observed in the age group 45-54 years, but the lowest $(11.4 \%)$ in the age group 55-74 years. In June 2020 , $63.7 \%$ of remote employees worked full-time, $18.3 \%$ worked regularly 3-5 days a week, and $7.8 \%$ worked regularly 1-2 days a week. $5.2 \%$ of employees worked remotely a few days a month, but $5.0 \%$ - regularly part-time or a few hours [6]

The authors of the study admit that probably a relatively large share of remote employees in the age group 45-54 years is related to the fact that this group has the largest number of senior specialists employed.

Figure 11 shows that with the end of the state of emergency (the first wave) in Latvia, the confidence indicators seasonally started to go up, but very slow in all sectors.

The authors also note that the COVID-19 has certainly had an impact on employee behaviour and economic performance of companies, but it is currently difficult to predict whether it will be a "yo-yo" or a long-term effect.

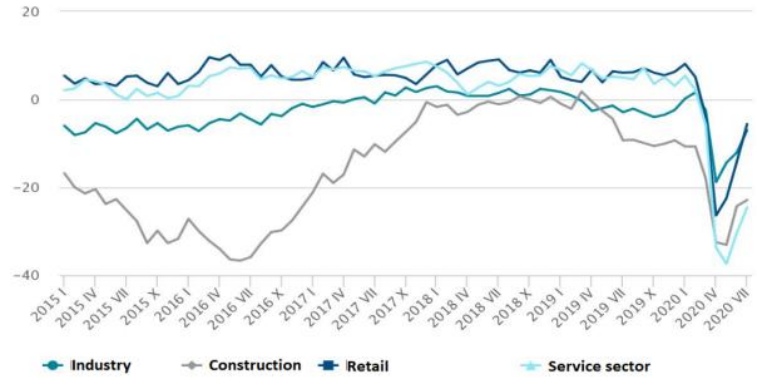

Fig. 11. Confidence indicators - seasonally adjusted data, balance \% [6]

\section{Discussion}

In the discussion part, it is important to understand whether the SMART and strong community can help overcome periods of crisis.

Open questions:

Will people and services stay in the countryside or return to the city after the end of the COVID-19 restrictions (see Figure 12)?

What tools are needed for successful operation remotely and can the Smart Village concept help?

Can a Smart and strong village or a community with a higher level of development better overcome crisis situations?

Dr. Bernie Jones discusses the Smart Village concept, "Unfortunately, in the world today, there are still around 1 billion people without access to electricity. 3 billion are still cooking on dangerous and inefficient stoves. Many of them live in remote rural communities. Until such communities have access to modern energy services, little progress can be made to develop their economies and improve their lives" (see Figure 10) [11].

In Latvia, from a digital point of view, there are no significant obstacles for communities and institutions to manage and communicate in digital format. Villages need mutual cooperation with each other and also among institutions. Cooperation would ensure both the identification of resources and the planning of the provision of missing resources.

The daily life of example coastal villages is based on a tourist service or a place of rest outside the city. Smart services successfully provide resource management, business activities, cultural event promotion, and bulletin board features.

The open question is whether social life can be provided remotely for a long time and where the reality remains - social and cultural activities?

To get a "full picture" of activities of communities and villages in the time of COVID-19 pandemic, it is important to combine concepts of Smart Village and strong community, which is based on the interaction scale (see Figure 2), because digital solutions cannot be assessed without taking into account the factors of human cooperation. 


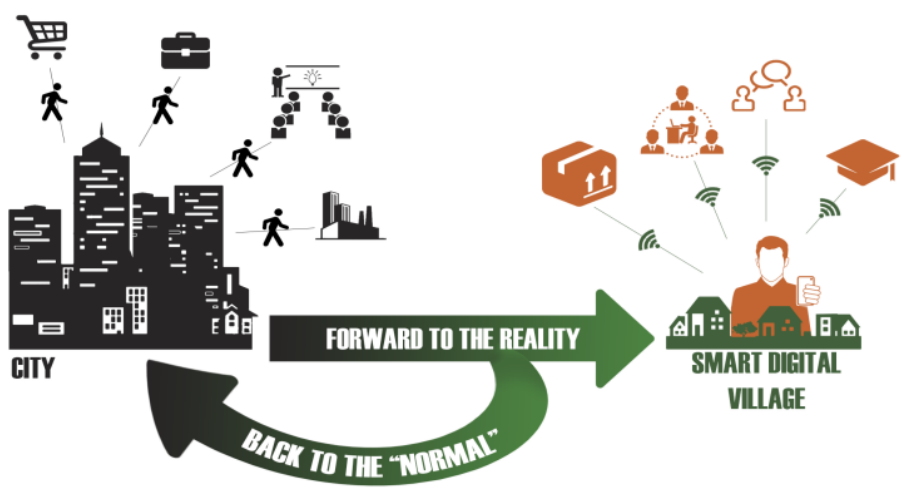

Fig. 12. Changes caused by the COVID-19 restrictions [developed by the authors]

TABLE 1

Advantages of Smart Villages and Strong Communities in the Time of Covid-19 Pandemic [developed by the authors]

\begin{tabular}{|c|c|c|}
\hline $\begin{array}{l}\text { Covid-19 pandemic } \\
\text { restriction field }\end{array}$ & $\begin{array}{l}\text { Village or community } \\
\text { groups (citizens, } \\
\text { entrepreneurs, local } \\
\text { administration) affected }\end{array}$ & $\begin{array}{l}\text { Smart village concept and community interaction } \\
\text { strengths as a reaction to restriction }\end{array}$ \\
\hline $\begin{array}{l}\text { Restriction of public } \\
\text { transport or suspension } \\
\text { of service }\end{array}$ & $\begin{array}{l}\text { Citizens, especially those } \\
\text { who use public transport } \\
\text { to get to work and services }\end{array}$ & $\begin{array}{l}\text { Teleworking opportunities, which, despite restrictions, } \\
\text { allowed for teleworking and remuneration } \\
\text { IT tools to ensure mutual public cooperation in private } \\
\text { transport sharing }\end{array}$ \\
\hline $\begin{array}{l}\text { Restriction of education } \\
\text { services or suspension } \\
\text { of service }\end{array}$ & $\begin{array}{l}\text { Citizens as recipients } \\
\text { of services } \\
\text { Entrepreneurs as parents } \\
\text { of children } \\
\text { Municipalities as service } \\
\text { providers }\end{array}$ & $\begin{array}{l}\text { There were many different IT and TV tools } \\
\text { implemented to provide distance learning with the least } \\
\text { possible impact on the quality of education } \\
\text { Sufficient quality of the Internet and the number of } \\
\text { computers allowed working and studying remotely } \\
\text { within one household at the same time, which } \\
\text { influenced business as little as possible }\end{array}$ \\
\hline $\begin{array}{l}\text { Restriction of culture } \\
\text { services or suspension } \\
\text { of service }\end{array}$ & $\begin{array}{l}\text { Citizens as recipients } \\
\text { of services } \\
\text { Municipalities as service } \\
\text { providers }\end{array}$ & $\begin{array}{l}\text { There were many different IT and TV tools } \\
\text { implemented to provide distance culture services, as } \\
\text { well as creative amateur processes as far as possible }\end{array}$ \\
\hline $\begin{array}{l}\text { Restrictions of health care } \\
\text { services or suspensions } \\
\text { of service }\end{array}$ & $\begin{array}{l}\text { Citizens as recipients } \\
\text { of services } \\
\text { Entrepreneurs as parents } \\
\text { of children } \\
\text { Municipalities as service } \\
\text { providers }\end{array}$ & $\begin{array}{l}\text { Various solutions based on telephone services and IT } \\
\text { services were introduced, which allowed receiving } \\
\text { services remotely without gathering and moving. At the } \\
\text { same time, it should be noted that in the health sector } \\
\text { only some services are provided as e-health services } \\
\text { due to their specifics }\end{array}$ \\
\hline $\begin{array}{l}\text { Self-isolation and } \\
\text { quarantine, a total ban on } \\
\text { moving outside the place } \\
\text { of residence }\end{array}$ & $\begin{array}{l}\text { Citizens as individuals } \\
\text { subject to self-isolation } \\
\text { or quarantine } \\
\text { Entrepreneurs as employers }\end{array}$ & $\begin{array}{l}\text { Self-help opportunities, focusing on the ability to } \\
\text { provide help and support to self-isolated or infected } \\
\text { community members through remote (non-contact) } \\
\text { tools and a strong cohesive community (this pandemic } \\
\text { forced almost everyone to self-isolation or } \\
\text { treatment at home) }\end{array}$ \\
\hline $\begin{array}{l}\text { Prohibitions on gathering } \\
\text { in public places, including } \\
\text { socialization points } \\
\text { (e.g., cafes) }\end{array}$ & $\begin{array}{l}\text { Citizens as beneficiaries } \\
\text { Entrepreneurs as service } \\
\text { providers }\end{array}$ & $\begin{array}{l}\text { In Latvia, the tourism and service sector had the } \\
\text { opportunity to attract more local market, which in the } \\
\text { long run would have an impact on habits -tourism and } \\
\text { recreation were also possible in the local region and in } \\
\text { Latvia as a whole (safe) } \\
\text { IT tools for meetings of interest groups }\end{array}$ \\
\hline $\begin{array}{l}\text { Restrictions on the } \\
\text { provision of day-to-day } \\
\text { services }\end{array}$ & $\begin{array}{l}\text { Citizens as beneficiaries } \\
\text { Entrepreneurs as service } \\
\text { providers }\end{array}$ & $\begin{array}{l}\text { There was an opportunity for a rapid reorientation of } \\
\text { direct sales to digital sales with contactless supplies, } \\
\text { both in the services and trade sectors }\end{array}$ \\
\hline $\begin{array}{l}\text { Recommendation to work } \\
\text { remotely, mass infection } \\
\text { at workplaces }\end{array}$ & $\begin{array}{l}\text { Residents as employees } \\
\text { Entrepreneurs as employers }\end{array}$ & $\begin{array}{l}\text { Opportunity to work remotely by using IT tools due to } \\
\text { limited access to public transport for employees, } \\
\text { limited access to work due to children having to learn } \\
\text { from home, including a reduced risk of cross- } \\
\text { contamination among employees }\end{array}$ \\
\hline
\end{tabular}


To answer open questions stated before, the authors of the study have collected information on how Smart and strong community strengths have affected the community/village ability to respond to restrictions and problems caused by COVID-19 pandemic in Latvia (see Table 1).

The information analysed in the study showed that in the conditions of the COVID-19 pandemic, there was a change in the habits of society as well as a change of residence to areas outside cities, and it was acknowledged that society was largely ready to switch to remote work and distance learning. Summarising information on changing population habits, national restrictions, and the strengths of the SMART village concept, it was identified that there were significant benefits for SMART villages and communities, as the local community chose a digital development path long ago; therefore, adapting to remote work, distance learning, cultural and public services did not cause many inconveniences. At the same time, the society was able to continue mutual communication and organise self-help. A big open question for post-Covid research remains: will people who chose to move out of the city during the pandemic choose to stay in the countryside or return to the city? This can make significant adjustments to the development of local communities in both potentially positive and negative ways.

\section{Conclusion}

From the above information and the data collected, it can be concluded that digital skills, digital equipment and services of local communities, as well as community cooperation skills have played a key role in overcoming the limitations and consequences of the COVID-19 pandemic. Smart villages and communities, as well as previously strong communities, were much better prepared for the crisis because they knew and were able to switch to digital solutions in different living spaces, as well as to provide mutual self-help.

Given the fact that smart communities and strong communities are usually closely linked to their living space and have purposefully chosen to live in small villages, it is considered that providing equivalent services even in the event of a large pandemic could not be a basis for change of the place of residence or business.

Examining the limitations of the pandemic and the communities' responses to them, it was concluded that smart communities, entrepreneurs, public service providers were able to adapt to a wide range of tools - IT solutions and applications, telephone-based services, social networks, online stores, etc. This is important evidence that IT infrastructure, networking and capacity, as well as digital connectivity and interoperability have been instrumental in overcoming the COVID-19 crisis.

In final conclusion, smart communities and strong communities were much more able to adapt to the constraints of the COVID-19 pandemic and to overcome the effects of the pandemic, as digital skills and strong community self-help played a key role.

Funding: This research was funded by the INTERREG Central Baltic programme project "Coast4us" within the P2 project priority - Sustainable use of the common resources, project number 627.

Conflicts of Interest: The authors declare no conflicts of interest.

\section{References}

1. Arhipova, I., Berzins, G., Brekis, E., et al. Pattern Identification by Factor Analysis for Regions with Similar Economic Activity Based on Mobile Communication Data. In: Arai K., Kapoor S., Bhatia R. (eds) Advances in Computing Networks, AISC, Springer, 2019, vol. 886, p. 561-569. https://doi.org/10.1007/978-3-030-03402-3_39

2. Business models for rural services. Briefing Working document. The European Network for Rural Development. European Commission. https://enrd.ec.europa.eu/sites/enrd/files/tg_smart-villages_briefing_business-models.pdf (accessed on 21.07.2020.)

3. Coronavirus disease (COVID-19) advice for the public. World Health Organization. Available online: https://www.who.int/ emergencies/diseases/novel-coronavir.Regarding Declaration of the Emergency Situation us-2019/advice-for-public (accessed on 10.08.2020).

4. Digital and Social Innovation in Rural Services. The European Agricultural Fund for Rural Development. The European Network for Rural Development. European Commission. Available online https://enrd.ec.europa.eu/sites/enrd/ files/enrd_publications/publi-eafrd-brochure-07-en_2018-0.pdf (accessed on 21.07.2020.)

5. Economic development index of Latvian regions. LU BVEF. LMT. 2019. Available online: https://www. lps.lv/uploads/docs_module/1_Latvijas\%20reǵionu\%20ekonomiskās\%20attīstības\%20indekss.pdf(accessed on 21.07.2020).

6. Employees working remotely. Socio-economic indicators under the impact of Covid-19. Central Statistical Bureau of Latvia. Available online: https://www.csb.gov.lv/en/statistics/covid19/Employees-working-remotely (accessed on 10.08.2020).

7. EU Action for Smart Villages. European Commission. Available online: https://ec.europa.eu/info/sites/info/files/foodfarming-fisheries/key_policies/documents/rur-dev-small-villages_en.pdf (accesed on 21.07.2020)

8. Haider, M. F., Siddique, A., R., Alam, S. An approach to implement frees space optical (FSO) technology for smart village energy autonomous systems. In: Far East. J. Electron. Commun. 2018, 18, 439-456. [CrossRef]

9. How California's communities can thrive in the digital age: Smart communities guidebook. San Diego State University. Center for International Communications, California. Department of Transportation. 1997. 33 p.

10. Impact of the implementation of emergency measures on the behaviour of mobile users. LU. LMT. Available online http://lmt.mstatic.lv/lmt/files/2020/lu-lmt-petijums-/pezentacija.pdf (accessed on 21.07.2020). 
11. New thinking for off-grid communities worldwide. Smart Villages Research Group. Available online: https://e4sv.org/svrghome-page/about-us-2/. (accessed on 10.08.2020).

12. Priority \& Focus Area Summaries. Connecting Rural Europe. The European Network for Rural Development. European Commission. https://enrd.ec.europa.eu/policy-in-action/rural-development-policy-figures/priority-focus-area-summaries_en (accessed on 21.07.2020)

13. Pudzis, E., Geipele, S., Geipele, I. Community Participation in Village Development: the Scale of Latvia. Baltic Journal of Real Estate Economics and Construction Management, 2016, 4(1), p. 84-99. https://doi.org/10.1515/bjreecm-2016-0007

14. Regarding Declaration of the Emergency Situation. Cabinet Order No. 103. Adopted 12 March 2020. Legal Acts of the Republic of Latvia. Available online: https://likumi.lv/ta/en/en/id/313191 (accessed on 10.08.2020).

15. Smart Villages - how to ensure that digital strategies benefit rural communities. European Network for Rural Development. Available online: https://enrd.ec.europa.eu/sites/enrd/files/enrd_publications/smart-villages_orientations_digital-strategies. pdf (accessed on 10.08.2020).

16. Smart Villages. The Pilot Project. Briefing note Brussels, 21-22 February 2019. Available online: https://digiteventimages.s3.amazonaws.com/5c0e6198801d2065233ff996-registrationfiletexteditor-1551115459927-smart-villages-briefingnote.pdf (accessed on 21.07.2020)

17. Statistical classification of economic activities in the European Community. NACE Rev. 2. Methodologiesand Working papers. Eurostat. Available online https://ec.europa.eu/eurostat/documents/3859598/5902521/KS-RA-07-015-EN.PDF (accessed on 21.07.2020)

18. Thomas, D. Community Development at Work: A Case of Obscurity in Accomplishment. London: Community Development Foundation. As cited in Meegan, R., Mitchell A., 2001. It's Not Community Round Here, It's Neighbourhood: Neighbourhood Change and Cohesion in Urban Regeneration Policies. Urban Studies, 1991, 38(12), p. 2167-2194.

19. Workin remotely in Latvia. Tvnet/Leta. 08.04.2020. Available online: https://www.tvnet.lv/6944989/vairak-neka-puseilatvijas-iedzivotaju-arkarteja-situacija-ir-lauts-stradat-attalinati (accessed on 21.07.2020).

\section{AUTHORS:}

Edgars Pudzis, Mg.Sc.Ing., MgPM, Researcher; PhD student; Riga Technical University, Institute of Civil Engineering and Real Estate Economics; 1 Kalku Street, Riga, Latvia, LV-1658; E-mail: edgars.pudzis@rtu.lv Una Krutova, Mg.Sc.Ing., Lecturer, Researcher; PhD student; Riga Technical University, Department of Geomatics; 1 Kalku Street, Riga, Latvia, LV-1658; E-mail: una.krutova@rtu.lv

Sanda Geipele, Dr., Associated Professor, Lead Researcher; Riga Technical University, Institute of Civil Engineering and Real Estate Economics; 1 Kalku Street, Riga, Latvia, LV-1658; E-mail: sanda.geipele@ rtu.lv Māris Kaḷinka, Dr.Sc.Ing., Associated Professor, Lead Researcher; Riga Technical University, Department of Geomatics; 1 Kalku Street, Riga, Latvia, LV-1658; E-mail: maris.kalinka@rtu.lv

Armands Auziņš, Dr., Associated Professor, Lead Researcher, Riga Technical University, Institute of Civil Engineering and Real Estate Economics; 1 Kalku Street, Riga, Latvia, LV-1658; E-mail: armands.auzins@ @rtu.lv

Kopsavilkums. COVID-19 pandēmija ir izraisījusi dažādas izmaiņas ikviena cilvēka dzīvē. Pētījumā analizētas ciematos un lauku teritorijās dz̄ivojošo cilvēku izveidotās viedās kopienas. Tiek analizēti gan ārējie faktori, kas ietekmē šādu kopienu darbību, gan arī īpašie apstākḷi, ko izraisīja COVID-19 pandēmijas pirmā viḷna periods (no 2020. gada marta līdz 2020. gada jūnijam). Apkopojot pamatinformāciju par viedajām kopienām, ārējiem faktoriem un īpašajiem apstākḷliem, kā arī izmantojot matemātiskās analīzes un salīdzināšanas metodes, pētījuma ietvaros tiek atzīmēti faktori, kas pandēmijas apstākḷos ir pozitīvi ietekmējuši kopienu veidošanos, skaidri norādot viedo kopienu ilgtspēju un attīstības priekšrocības Latvijā. 